\title{
The Different "Speeds" of the Countries in WB toward EU Evaluations of Last Developments
}

\author{
Dr. Eva Teqja \\ Aleksander Moisiu University, Durres, Albania
}

Doi:10.5901/ajis.2014.v3n3p516

\begin{abstract}
This paper analyzes the key moments and challenges that has passed the Western Balkans through the process of European integration. The main criteria for EU integration and the main problems and challenges of our region, are described in the paper. The problems and incoherence of EU countries regarding the attitude towards the Western Balkans, the various options of integration speeds of Balkan countries, there have been exposed also. The purpose of this study consists not just in deepening in yesterday's developments in this region but in all the inspections of the possibilities, opportunities and standards for the final approach also, aiming a full recognition of Western Balkans in the prolonged transition of society's transformation towards a new social and political system. Seen in historical perspective, in many barriers of mentality formation of these people, in peculiarities that history of the region offers ranging from nationalism to the complete communist isolation, the wars waged in their name, this study also provides the opportunity of reflection on the necessity of the development of the region as a whole, where development speeds are not far from each other. Comparative methods, surveys and official reports of the European institutions are used for the realization of this study. The study is based also on the identification of similarities and differences of these countries through using a vast historical and contemporary literature. We try to answer questions related to the future of this region and two sided challenges that this integration involves.
\end{abstract}

Keywords: integration, criteria, development, transition

\section{Introduction}

EU accession is seen as crucial to a successful transformation in Western Balkans. Further progress with the EU accession process is of great importance for the continuation of institutional reforms and establishment of a functioning market economy across the Western Balkans. Fulfilling the Copenhagen criteria and achieving further progress in regional cooperation would also increase political stability, which was recognized as a serious obstacle to the economic stabilization of the region.

This paper analyzes the key moments and challenges that has passed the Western Balkans through the process of European integration. The main criteria for EU integration and the main problems and challenges of our region, are described in the paper. Our focus is the attitude of EU countries towards the Western Balkans, the different integration speeds of Balkan countries, there have been exposed also.

The paper is focused not just in past developments in this region, but in all the inspections of the possibilities, opportunities and standards for the final approach. Comparative methods, surveys and official reports of the European institutions are used for the realization of this study. The study is based also on the identification of similarities and differences of these countries through using a vast historical and contemporary literature. We try to answer questions related to the future of this region. This paper discusses how different is the position of the Western Balkan countries in the enlargement process and what are the policy options in the new circumstances from the position of the policy-taker, a potential EU member state.

\section{Western Balkans: Achievements and Challenges}

The $28 \mathrm{EU}$ member states granted Albania the status of official EU membership candidate on 24 June. This is the next step in Albania's long road to becoming an EU member state, and is recognition of recent reforms in the country. Albania is now the sixth accession candidate along with Turkey, Montenegro, Serbia, Macedonia and Iceland. Talks with these countries have come to a standstill, and unlike Albania, they are taking steps to leave behind their candidate status. European affairs ministers in Luxembourg concluded that progress in the membership process is still conditional on further efforts (Euraktiv, 2014).

In their conclusions, they state that Albania must "intensify its anti-corruption efforts and implement its anticorruption strategy and, reform of the public administration and the judiciary, the fight against organized crime and 
corruption, the protection of human rights and anti-discrimination policies including in the area of minorities and their equal treatment". Štefan Füle, the European commissioner in charge of enlargement spoke to EurActiv and made clear that the EU already has too many members, but Albania is a special case. Indeed, geographical stability plays an important role in Albania's membership process. "Behind the Albania candidate status lie concerns over Kosovo and real political stakes for the entire Balkans region. The European path is creating a peaceful future for the region." (Ibid).

But the Europeans are doubtful about the fulfillment of the criteria by the aspirant countries. For Füle "both member states and candidate countries got tired by the slowly proceeding enlargement process. Above all, the last enlargement of Romania and Bulgaria brought a lot of questions about the credibility of the whole process. Candidate states should prove that the adopted legislation is working. Our recommendations are connected with funding. If the country refuses to make reforms in a particular area, we can redirect a significant amount of money to another country willing to do it" (European Commission, 2014).

The accession struggle has demonstrated a lot of difficulties. According to Milan Nič "the euro crisis has not killed the enlargement process. But, the first EU enlargement since the euro crisis will be also be the last in this decade, at least for South-Eastern Europe". (Nič, 2013). He ask how the EU's transformative power can be sustained for this fragile corner of Europe that is gradually emerging from its troubled history - and how this "incomplete mission" can be kept on the EU's political agenda at a time when it is undergoing its own great transformation (Ibid).

It is made clear by many analysts that full EU membership, even for the most credible aspirants is not realistic before 2020 taking in consideration that the accession process took Croatia more than eight years to complete. Moreover, it is true that due to lessons learned from the last round of enlargement to Bulgaria and Romania, and under the pressure of enlargement-sceptic EU members, the whole accession process has become more difficult and rigorous.

If we try to observe now the countries, we find that the entry of Croatia into the EU is a real test of the benefits that European integration can bring to a region. Nič's questions are: "Will the inflow of foreign direct investment to Croatia increase? Will EU funds help to create more growth and infrastructure development?" And the answer is that if Croatia is unable to leverage the opportunities EU membership brings, it would have wider repercussions for the region.

Balkan economies are now struggling with a recession, characterized by a unemployment. Serbia has an unemployment rate above $25 \%$, Macedonia over $30 \%$ and Kosovo over $40 \%$. There is no doubt that the Western Balkans will now face a difficult period. Now, more than ever, they must show the Union that they can be good members and that the negative stereotypes that will be put about by those hostile to enlargement do no match the realities on the ground (Lindsay, 2013). They need to reform and continue their efforts to overcome outstanding problems with their neighbors. At this difficult time, Balkan policy-makers must also realise that they can, and must, play their part in helping others to help them (Ibid).

The director of the Center for Research of Southeast Europe Florian Bieber in his overview of the BiEPAG analysis, 2014, argue that the new European Commission will have to make a new strategy and plan for the future enlargement. "We need to start the talks with all the countries in the region, and the conditions at the beginning should be moved to the end of the negotiations, because the negotiations themselves have the potential to resolve some internal issues in the candidate countries". Competition reforms in the countries of the region, in his opinion, are the key to a better paced progress towards the EU, but this can only happen if the certainty of membership is confirmed in the political practice (Bieber, 2014).

\section{European Perspectives of Western Balkan Countries}

The candidate countries for EU membership had to fulfill the economic criteria approved by the European Council in Copenhagen in 1993 today it became clear that they are insufficient. And these criteria are the existence of a functioning market economy and a capacity to handle competitive pressures and the market forces in the EU. Almost all Western Balkan countries have no market economy status yet (Marini, 2014).

According to Adelam Marini, the countries from former Yugoslavia and Albania have a lot of common problems, but also some differences, which are rather to be qualified as insignificant. All of them suffer from extremely high unemployment, especially among the young people, of widespread corruption, a growing public sector, unjustified optimism when planning the budget and, in general, of bad management of public finances( Ibid). All the six countries from the Western Balkans suffer from a huge share of the informal economy. The weak fight with corruption and the weak rule of law also pose a serious impediment for the economic development of the countries in the region, as in all cases the Commission reports weak to some progress(lbid).

The issue of financial crisis still remains a matter of concern for Western Balkan countries and Europe as a whole. In moments when the economies of these countries recover from recessions of global financial crisis, a new crisis 
threatens the region. (Murat Sadiku, Luljeta Sadiku, and Nimete Berisha, 2013). In her analyses, Slavica Penev in 2012 confirm that the Western Balkan countries witnessed strong economic growth in the pre-crisis period, but the growth was based on high domestic consumption linked to fast credit growth, and was accompanied by a widening current account deficit and increasing private sector debt". According to her this growth was interrupted when the global financial crisis was transmitted to the region. In 2009, GDP declined in Bosnia and Herzegovina, Macedonia, Montenegro, and Serbia, while in Albania and Kosovo the growth was slower compared to the pre-crisis period. The consolidation of the economic recovery that began in 2010 resulted in moderate positive growth in all countries of the region. While some recovery seemed evident in the first half of 2011, economic activity weakened in the second half of the year and the first half of 2012 (Penev, 2012). Data shows us that the short-term economic prospects for the Western Balkan region remain weak and vulnerabilities have increased as a result of the Euro zone crisis.

Table 1: Western Balkans: Real GDP growth and projections, percentage change, 2001-2013

\begin{tabular}{|l|c|c|c|c|c|c|c|c|c|}
\hline \multicolumn{9}{|c|}{} & \multicolumn{10}{l|}{$\mathbf{l}$} & \\
\hline & $2001-2003$ & $2004-2006$ & 2007 & 2008 & 2009 & 2010 & 2011 & 2012 & $2013^{\star}$ \\
\hline Albania & 6 & 5.6 & 6 & 7.7 & 3.6 & 3.3 & 3 & 0.5 & 1.7 \\
\hline BiH & 4.3 & 5.6 & 6.8 & 6 & -2.8 & 0.7 & 1.3 & 0 & 0.5 \\
\hline Macedonia & -0.3 & 4.1 & 5.9 & 4.8 & -1 & 1.9 & 3.1 & 1 & 2.2 \\
\hline Montenegro & 1.8 & 5.7 & 10.7 & 7.5 & -5.7 & 2.5 & 2.4 & 0.2 & 1.5 \\
\hline Serbia & 4 & 7 & 6.9 & 5.5 & -3.5 & 1 & 1.6 & -0.5 & 2.0 \\
\hline Kosovo & n.a. & 3.3 & 6.3 & 6.9 & 2.9 & 3.9 & 5 & 3.8 & 2.6 \\
\hline Western Balkans & 3.2 & 5.6 & 7.3 & 6.4 & -1.1 & 2.2 & 2.7 & 0.8 & 1.75 \\
\hline
\end{tabular}

Source: IMF, World Economic Outlook, October 2010, April 2012, July 2012, October 2012, October 2013*, and EBRD database.

The entire region (with the exception of Macedonia) lags significantly behind the average rankings of EU-10 member states (47th) (Figure 1), indicating a much more burdensome environment for doing business in the Webs, with the exception of Macedonia and Montenegro.

Figure 1: World Bank Doing Business Rankings: Ease of Doing Business Rank, 2009-2013

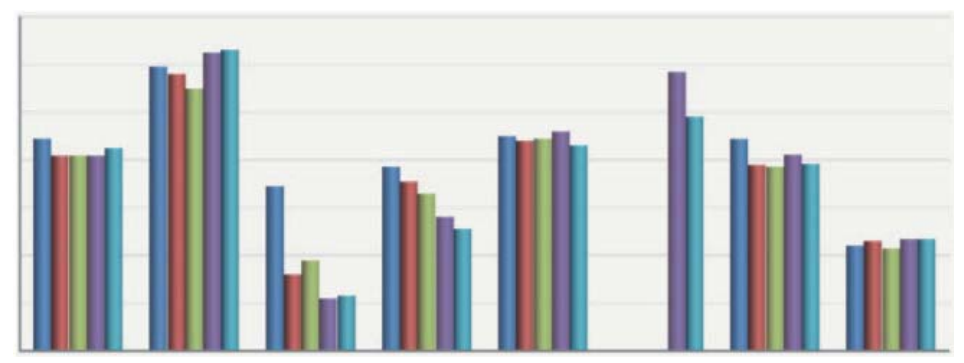

Source: World Bank Doing Business database

Note 1: Ease of Doing Business Rank among 185 countries in 2013.

All Western Balkan countries are in the second development stage, with economies that are

primarily efficiency-driven. At this stage, competitiveness is increasingly driven by higher education and training, efficient goods markets, well-functioning labour markets, developed financial markets, the ability to harness the benefits of existing technologies, and a large domestic or foreign market. (Table 2). 
Table 2: WEF Global Competitiveness pillars of competitiveness, rankings, 2012-2013

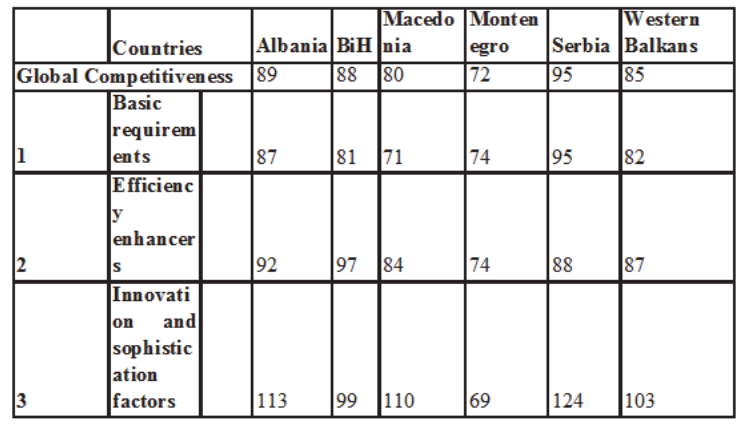

Source: World Economic Forum (WEF): The Global Competitiveness Reports

The global crisis has revealed the vulnerabilities of the growth pattern in the Western Balkan countries, which is based on domestic demand and financed by foreign capital inflows. In order to enhance the economy's resilience through sustainable export-led growth, Western Balkan countries need to step up their structural reforms and deal with the problem of unemployment. The global financial and economic crisis exposed the vulnerabilities of a growth paradigm that was based on domestic demand financed largely by borrowing abroad. The attempts towards strengthening the financial framework and the quality of public finances gave some results in 2010 and 2011, but recent worsening in this area resulted in an increased budget deficit and a further increase of general government debt (European Commission, 2011b).

Table3: SEE6 Real GDP Growth

\begin{tabular}{|l|c|c|c|c|c|c|}
\hline & $\begin{array}{c}\text { Projected } \\
\mathbf{2 0 1 2}\end{array}$ & $\begin{array}{c}\text { Actual } \\
\mathbf{2 0 1 2}\end{array}$ & $\begin{array}{c}\text { Estimated H1 } \\
\text { 2012 }\end{array}$ & $\begin{array}{c}\text { Estimated H2 } \\
\mathbf{2 0 1 2}\end{array}$ & $\begin{array}{c}\text { Estimated } \\
\mathbf{2 0 1 3}\end{array}$ & $\begin{array}{c}\text { Projected } \\
\mathbf{2 0 1 4}\end{array}$ \\
\hline ALB & 0.8 & 1.6 & 0.9 & 2.2 & 1.8 & 2 \\
\hline BIH & 0 & -0.7 & -0.2 & -1.1 & 0.5 & 2 \\
\hline KOS & 3.6 & 2.3 & 3.6 & 1.1 & 3.1 & 4.3 \\
\hline MKD & 0 & -0.3 & -1.1 & 0.4 & 1.4 & 2.5 \\
\hline MNE & 0.2 & -0.6 & -0.9 & -0.2 & 1.2 & 1.5 \\
\hline SRB & -2 & -1.7 & -1.5 & -1.9 & 2 & 2.7 \\
\hline Weighted av. & -0.5 & -0.6 & -0.5 & -0.7 & 1.7 & 2.5 \\
\hline
\end{tabular}

The progress reports on the Western Balkans 2012-2013 point to the fact that despite the rather unfavorable environment in the Eurozone, the EU is still willing to maintain its role as a driver for transformation in the region. This was evident in the Commission's changing methodology diversifying the instruments at its disposal to address the specific challenges in each country. The World Bank suggest to the region:What SEE6 countries now need to do is to sustain the fragile recovery and push for job creation. This will require aggressive job-oriented policies.

Table 4: World GDP growth and growth prospects, 2007-2013

\begin{tabular}{|l|c|c|c|c|c|c|c|}
\hline & 2007 & 2008 & 2009 & 2010 & 2011 & 2012 & 2013 \\
\hline World & 5.2 & 3.0 & -0.6 & 5.3 & 3.9 & 3.5 & 3.9 \\
\hline EU-10 & 6.3 & 4.2 & -3.6 & 2.2 & 3.4 & 2.4 & 2.2 \\
\hline Western Balkans & 7.1 & 6.4 & -1.1 & 2.2 & 2.7 & 0.8 & 2.1 \\
\hline
\end{tabular}

Source: IMF, World Economic Outlook, October 2010, April 2012 and July 2012, and WIIW July 2012

The Balkan countries may study and choose to introduce the best proposals for economic governance, even if they are not mandatory. In that way, they'll not only have guarantees of financial stability and safeguards against domestic populist 
temptations (e.g. in case such rules are enshrined into the constitution), but also convince their EU counterparts that they are serious in pursuing prudent policies (Lessenski, 2010: 10).

\section{The New European Agenda on Western Balkans}

Western Balkan countries have achieved significant progress in the last years. Croatia achieved the best results in the region in all indicators. (Škuflić, 2010). Actually, the EU is strengthening its conditionality, control, and pressure on the Western Balkans during the earlier stages of the pre-association and pre-candidacy process (Othon Anastasakis, 2012). Within this long journey, the various steps of the SAp acquire a special significance as both targets and rewards for the applicants; from the feasibility study of the SAp to the start of negotiations for a Stabilisation and Association Agreement (SAA), the conclusion of SAA negotiations, the initialling of the SAA, the signing of the SAA, the ratification process, the EU candidacy, and the start of accession talks; all these stages are being used to maximize the potential leverage of the EU on applicant states. Progress from one step to the next is linked closely with the fulfillment of criteria and a wellendowed political conditionality (Ibid). "The degree to which democracy is internalized, however, depends on the domestic factors within a country that shape, and circumscribe democratic norms." (Elbasani 2009: 25). Analysts like Archick and Morelli, 2014 argue that the carefully managed process of enlargement is one of the EU's most powerful policy tools (Archick and Morelli, 2014:1-17). In the Enlargement Strategy and Main Challenges 2013-2014 declared by the European Commission we see this situation of the countries in the region:

Albania and the EU completed a Stabilization and Association Agreement in June 2006. In April 2009, the SAA entered into force and Albania formally applied to join the EU. In October 2012, the European Commission asserted that Albania was making good progress toward meeting the political criteria for membership, and recommended that Albania be granted candidate status, subject to the completion of reforms in the areas of the judiciary, public administration, and parliamentary rules of procedure. In October 2013, the Commission stated that Albania had met the reform requirements; the Commission affirmed that Albania should now be granted candidate status. In December 2013, however, EU leaders were unable to reach agreement on naming Albania as an EU candidate country. EU leaders granted Albania candidate status in 24 June 2014. In addition to corruption and organized crime, other areas of EU concern in Albania include rule of law issues, and the protection of property rights.

Macedonia: Within a decade of gaining independence, Macedonia concluded a Stabilization and Association Agreement (SAA) with the EU in 2001 to govern relations. It applied for EU membership in March 2004. The EU named Macedonia as an official EU candidate in December 2005. The European Commission has recommended opening membership talks with Macedonia since 2009. According to the Commission, Macedonia is sufficiently fulfilling the political and economic criteria for membership, although EU officials have expressed some concerns about the country's democratic progress. The EU continues to urge Macedonia to complete necessary reforms aimed at improving the rule of law, protecting freedom of expression, promoting the independence of the judiciary, and strengthening anti-corruption efforts. Macedonia has not yet secured a start date for accession negotiations.

Montenegro: Montenegro and the EU began talks on a Stabilization and Association Agreement. The SAA was signed in October 2007. Macedonia applied for EU membership in December 2008 and was granted candidate status in December 2010. The EU opened accession negotiations with Montenegro in June 2012. As of December 2013, seven negotiating chapters had been opened, and two of these provisionally closed. EU officials acknowledge Montenegro's solid progress toward meeting EU standards, but they also assert that more work is needed. Key challenges facing Montenegro include improving the rule of law, fighting corruption and organized crime, enhancing the independence of the judiciary, guaranteeing freedom of expression, strengthening administrative capacity, and improving the business environment.

Serbia: Serbian-EU relations were difficult and Serbia's path toward eventual EU membership faced several obstacles. As part of EU efforts to boost pro-Western political forces in the country, the EU concluded a Stabilization and Association Agreement with Serbia in April 2008. In December 2009, Serbia submitted its formal application for EU membership. The EU named Serbia as an official candidate in March 2012. Talks between Serbia and Kosovo continued under EU auspices. In December 2012, EU leaders agreed to assess the possibility of opening negotiations with Serbia in spring 2013, following a Commission report on Serbia's progress toward meeting all EU membership criteria, and especially on whether Serbia had done enough to enhance its relations with Kosovo. In December 2013, EU member states endorsed opening accession talks with Serbia, and the first negotiating session took place in late January 2014. The EU also urged Serbia to continue its efforts toward improving the rule of law, reforming the judiciary, fighting corruption and organized crime, protecting minority rights and media freedoms, and enhancing its business environment.

Bosnia-Herzegovina has not yet applied for EU membership. Bosnia and the EU signed a Stabilization and 
Association Agreement in June 2008, which was ratified in 2011. However, as Bosnia has not met the remaining requirements, the SAA has not entered into force and EU relations are still governed by an interim agreement. The EU has established a High Level Dialogue on the Accession Process (HLDAP) with Bosnian political representatives to encourage reforms and to facilitate coordination between the various levels of Bosnia's government so that the country can speak with one voice on EU matters, but the Commission reports that no progress has been achieved to date. The EU continues to maintain a small peacekeeping force in Bosnia.

Kosovo declared its independence from Serbia in February 2008. Kosovo participates in the Stabilization and Association Process and receives pre-accession financial assistance from the EU, but efforts to forge an SAA have been complicated by the lack of full EU diplomatic recognition. In October 2012, the European Commission announced the results of a feasibility study, which found that the EU could conclude an SAA with Kosovo. EU leaders agreed to begin negotiations on an SAA with Kosovo; these negotiations began in October 2013 and the Commission hopes to conclude them in 2014. Key EU concerns in Kosovo include the rule of law, protection of minorities, corruption, and organized crime.

The only way in which the Balkan integration can be fully successful is by creating a policy climate that would encourage a change in the perception of the region as related to the Europeanization process, in the sense of mutually reinforcing realities that need to complement rather than exclude each other (Gligor, 2008:1-11). Elda Nasho, an Albanian researcher, argues in 2011 that at the national level Albania is under pressure to satisfy the imposed conditionality issues. This contribution focuses on the influence of the EU and the domestic actors on the democratization process in Albania. It's important for the EU to continue using its leverage through the mechanism of conditionality and through the accession prospect in order to lead the Western Balkan countries to further consolidate their democracy and carry out their reforms. The other two Albanian researchers, Vasjari and Shtupi, argue the importance not only of the accession regarding the acquis communautaire for national legislation, but for the effective application through appropriate administrative and judicial structures"(Vasjari, Shtupi, 2013). Although the EU's role in the Western Balkans remains crucial as an "anchor" of stability, as a one-way path to prosperity and as a goal to be aspired to may be losing its appeal for some of these countries (Panagiotou, 2012)

According to Dominik Tolksdorf in 2013 "the membership perspective of the Western Balkan states does not only depend on progress in the region itself, but also on developments within the EU. Citizens in the region are aware that new enlargement rounds are not on the top of the EU leaders' agenda". While the latter will for the next two to three years focus on tackling economic and financial issues, it is difficult to predict in which direction European integration leads ( Ibid).

\section{Conclusions}

The struggle conducted by Croatia demonstrates that all applicant countries will be "scanned" thoroughly by the European Commission. Since the beginning of the membership negotiations in October 2005, it took Croatia eight years to finally join the Union. Given these circumstances, it can be assumed that it will take at least five to ten years until another state of the region will become an EU member - under the condition that the Union has acquired a new "absorption capacity". The public opinion in the Balkans are aware that their country's membership is in a rather distant future.

The Balkans will follow a similar curve to recovery, but this depends both on their main partners' recovery and on their capacity to capitalize on the positive trends; The Balkans have to catch up with their Western counterparts and they need much higher and more high-quality growth.

The EU is strengthening its conditionality, control, and pressure on the Western Balkans during the earlier stages of the pre-association and pre-candidacy process. Within this long journey, the various steps of the SAP acquire a special significance as both targets and rewards for the applicants; from the feasibility study of the SAP to the start of negotiations for a Stabilization and Association Agreement (SAA), the conclusion of SAA negotiations, the initialing of the SAA, the signing of the SAA, the ratification process, the EU candidacy, and the start of accession talks; all these stages are being used to maximize the potential leverage of the EU on applicant states. Progress from one step to the next is linked closely with the fulfillment of criteria and a well-endowed political conditionality. 


\section{References}

Adelina Marini.(2014) The Western Balkan Economies- Informal, with Huge Unemployment and un reforming. Zagreb.

Arolda Elbasani (2009). EU Administrative Conditionality and Domestic Downloading. The Limits of Europeanization in Challenging Contexts. KFG Working Paper Nr. 2. Berlin.

Arjan Vasjari, Indrit Shtupi. (2013). The Democratic Impact of European Integration: Case Study of Albania. Mediterranean Journal of Social Sciences. Sapienza University of Rome.

Dominik Tolksdorf.(2013). The EU and the Western Balkans: Challenges for the Pre-Accession Process in 2013. Institute for European Studies. Brussel.

Elda Nasho.(2011). Albanian integration into the UE: security, Europeanization, democratization: which project for the democracy? Reykjavik. p: 1-9.

European Commission, Enlargement Strategy and Main Challenges 2013-2014, October 16, 2013. Brussels.

Florian Bleber (2014). "The Unfulfilled Promise: Completing the Balkan Enlargement". EFB. Programme Areas. Initiatives. Balkan in Europe Policy Advisory Group. Belgrade. http://balkanfund.org/2014/06/the-unfulfilled-promise-completing-the-balkanenlargement-policy-paper-presented-in-belgrade-30-of-may-2014-belgrade/

James Ker-Lindsay (2013) Western Balkans will need champions in an increasingly enlargement sceptic EU. CEPI http://www.cepolicy.org/publications/eus-role-western-balkans-after-croatian-accession

Kristin Archick Vincent L. Morelli February.( 2014). European Union Enlargement Congressional Research Service. RS21344 European Union Enlargement Congressional Research Service. p:1-17

Marin Lessenski. (2010). The Western Balkans: Between The Economic Crisis And The European Perspective. Institute For Regional And International Studies. Sofia

Madalina Gligor (2011) Broadening the Perspectives of Incompatibility: Accounting for Europeanization and Balkanness as Complementary Realities 4th HEIRS.Université Libre de Bruxelles. p: 1-11.

Milan Nič (2013) The EU's role in the Western Balkans after last accession Western Balkans Policy briefs. The World Bank, 2012 report

Murat Sadiku, Luljeta Sadiku, and Nimete Berisha (2013). The Western Balkan Economies, like a basic criterias for the integration process. The Financial Crisis in Greece and Its Impacts on Western Balkan Countries. Prishtina.

Outlook for Macroeconomic Development in the Western Balkans: Data Update IFI Coordination Office. May 2013. IMF, World Economic Outlook (October 2012 and April 2013).

Othon Anastasakis(2008) The EU's political conditionality in the Western Balkans: towards a more pragmatic approach. University of Oxford.

Raporti i Zhvillimit Ekonomik i Evropës Juglindore Nr. 3 i Bankës Botërore (2013).

Ekonomia e Evropës Juglindore Tkurret në 2012, Përballet me Rreziqe në 2013. Prishtinë www.worldbank.org/eca/seerer.

Report No. 78505-ECA (2013) South East Europe Regular Economic Report | No.4 From Double-Dip Recession to Fragile Recovery, Poverty Reduction and Economic Management Unit Europe and Central Asia.

Ritsa Panagiotou (2012). The EU and the Western Balkans: Challenges for the Pre-Accession Process in 2013 Robert Schuman Centre For Advanced Studies. European University Institute, Florence EUI Working Paper RSCAS 2012/64 2012. Italy. www.eui.eu/RSCAS/Publications/ 248FSTO040Batr.06hiyuS1

Slavica Penev. (2012). Economic and European perspectives for the Western Balkan countries Published by Westminster Foundation for Democracy (WFD) (Valjevo : Topalović).

Škuflić Lorena. (2010). Transition Process in the Western Balkans: How Much Successful Is This Story? University of Zagreb, School of Economics and Business, Zagreb.

Štefan Füle. (2014) Bulgaria and Romania's accession questioned the credibility of EU enlargement. Published: 26/06/2014 http://www.euractiv.com/sections/enlargement/fule-bulgaria-and-romanias-accession-questioned-credibility-eu-enlargement.

Štefan Füle. (2014) Štefan Füle. Enlargement and Western Balkans what's next? European Commission - SPEECH/14/423 Published: 03/06/2014 http://www.euractiv.com/enlargement/fuele-enlargement-brings-positiv-interview-514283 